$\begin{gathered}\text { Науковий вісник Нлту України } \\ \text { Scientific Bulletin of UNFU } \\ \text { https://nv.nltu.edu.ua }\end{gathered}$
$\begin{aligned} & \text { https://doi.org/10.36930/40300509 (i) ISSN 1994-7836 (print) } \\ & \text { Article received 03.11.2020 p. } \\ & \text { ISSN 2519-2477 (online) }\end{aligned}$
$\begin{aligned} & \text { Article accepted 12.10.2020 p. } \\ & \text { UDC 631.425.6:574.23 }\end{aligned}$

П. В. Босак, В. В. Попович, В. Ф. Піндер, О. В. Стокалюк

Львівський державний університет безпеки життєдіяльності, м. Львів, Украӥна

\title{
ТЕМПЕРАТУРА ЗАЙМАННЯ ТА САМОЗАЙМАННЯ НАЙПОШИРЕНІШИХ ДЕРЕВНИХ ПОРІД ТЕРИКОНІВ
}

Екологічна небезпека шахтних породних відвалів в умовах урбанізованого середовища є високою. Для їі оцінювання у кожному конкретному випадку потрібно проводити екологічний моніторинг для розроблення природоохоронних заходів 3 мінімізації негативних їх чинників. Наголошено на чинниках, які призводять до самозаймання вугільних відвалів, та на підставі наукових джерел детально описано хімізм досліджуваних процесів. Окиснення і горіння породних відвалів супроводжується значним виділенням водяної пари, яка $є$ мінералоутворюючим середовищем для більшої частини мінералів: сульфатів, гідрокарбонатів, карбонатів, фосфатів, арсенатів. Окрім цього, внаслідок окиснення виділяється вуглекислота, нітроген оксид (IV), який з водою утворює нітратну кислоту. У разі нестачі кисню в осередках горіння в парогазових викидах міститися сірководень, вуглеводні, амоніак, оксид карбону (II). Акцентовано увагу на тому, що важливе значення в процесах окиснення належить сірці. Окиснення вугілля посилюється на дрібних частинках, через збільшення площі поверхні, що доступна для окиснення. Висвітлено, що найнадійнішим способом захисту від самозаймання вугільних відвалів є створення на їх поверхні рослинного покриву. Процес формування рослинного покриву є дуже важливим, адже при цьому відбувається як накопичення важких металів у рослинах, так і зв'язування субстрату їхніми коренями й кореневищами, що зменшує процес вивітрювання та вимивання породи, яка містить велику кількість важких металів. Встановлено показники температури займання та самозаймання зразків деревних порід відвалів вугільних шахт згідно з ДСТУ8829:2019. Дослідження показників займання та самозаймання твердих речовин і матеріалів здійснювали у весняний та літній періоди. Досліджуваними об'єктами були проби листя та деревина з терикону шахти Нововолинського гірничопромислового району (Волинська область, м. Нововолинськ). Встановлено, що для сосни звичайної температура займання становить: $+225^{\circ} \mathrm{C}$, а самозаймання $+475{ }^{\circ} \mathrm{C}$. Температура займання берези повислої $+260{ }^{\circ} \mathrm{C}$, дуба звичайного $+275^{\circ} \mathrm{C}$, козячої верби $+280{ }^{\circ} \mathrm{C}$, температура самозаймання - берези повислої $+470{ }^{\circ} \mathrm{C}$, дуба звичайного $+475{ }^{\circ} \mathrm{C}$, верби козячої $+473{ }^{\circ} \mathrm{C}$. Температура займання берези повислої, дуба звичайного, верби козячої ніж сосни звичайної робить їх перспективними породами дерев для запобігання самозайманню вугільних відвалів. район.

Ключові слова: екологічна безпека; екологічна небезпека; горіння; терикон; Нововолинський гірничопромисловий

\section{Вступ}

Найпоширенішими техногенними екотопами на території Львівсько-Волинського вугільного басейну є терикони вугільних шахт і одним з основних є Нововолинський гірничопромисловий район, який розташований на межі Львівської та Волинської областей. На сьогодні добувну галузь в Нововолинському гірничопромисловому районі представляють 4 вугільних підприємства, а саме: шахта "Бужанська", шахта № 9 "Нововолинська", шахта № 10 "Нововолинська" та шахта № 1 "Нововолинська" (з 21 жовтня 2019 р. відбувається процес підготовки до ліквідації шахти № 1 "Нововолинська"). За 2019 р. із них видобуто понад 70 тис. т ву- гілля, із яких вже сформовано понад 30 відвалів із приблизною масою шахтних порід понад 30 млн т $[16,17]$.

Породи, які йдуть у відвал, утворюються внаслідок видобутку вугілля (52 \%) і їх ремонту (48 \%). Такі шахтні породні відвали складуються поблизу стовбурів шахт у вигляді териконів висотою до 60-80 м і відвалів хребтової форми (92\%), рідше - плоских відвалів (8\%). Середній літологічний склад відвалів відображає склад вугленосної товщі. Це аргіліти (60-80\%), алевроліти (10-30\%), пісковики (4-10\%), вапняки (рідко до 6 \%), а також значні домішки вугілля (6-20\%) [15].

Екологічна небезпека шахтних породних відвалів в умовах урбанізованого середовища $є$ негативною. Це

Інформація про авторів:

Босак Павло Володимирович, викладач, кафедра екологічної безпеки. Email: bosakp@meta.ua; https://orcid.org/0000-0002-0303-544X

Попович Василь Васильович, д-р техн. наук, доцент, начальник Навчально-наукового інституту цивільного захисту. Email: popovich2007@ukr.net; https://orcid.org/0000-0003-2857-0147

Піндер Володимир Федорович, проректор по роботі з персоналом. Email: vova290752@gmail.com; https://orcid.org/0000-0003-2977-3560

Стокалюк Олег Володимирович, канд. техн. наук, заступник начальника Навчально-наукового інституту цивільного захисту. Email: Stokoleg@gmail.com; https://orcid.org/0000-0002-9877-771X

Цитування за ДСтУ: Босак П. В., Попович В. В., Піндер В. Ф., О. В. Стокалюк Температура займання та самозаймання найпоширеніших деревних порід териконів. Науковий вісник НлтУ України. 2020, т. 30, № 5. С. 53-58.

Citation APA: Bosak, P. V., Popovych, V. V., Pinder, V. F., \& Stokalyuk, O. V. (2020). Ignition and spontaneous ignition temperature of widespread woody species on the waste heaps. Scientific Bulletin of UNFU, 30(5), 53-58. https://doi.org/10.36930/40300509 
передусім спільний вплив відвалів, які горять за змикання зон поширення продуктів горіння, а також хімічна та радіологічна токсикація грунтів і вод та порушення рівноваги геологічного, фізичного, механічного стану гірського масиву. Одним 3 найбільш негативних наслідків вугільних териконів $\epsilon$ їх самозаймання, яке зумовлено низкою чинників. Першим чинником $\epsilon$ вільний доступ кисню всередину тіла відвалу. Його, водночас, зумовлюють схили і велика площа внутрішнього простору. Схил відвалу визначається на технологічному етапі рекультивації, в разі недотримання заходів із запобігання самозайманню і формуванню схилів крутизною більше $10^{\circ}$ ризик виникнення самозаймання підвищується. Для зменшення доступу кисню всередину відвалу, породи ущільнюють, зменшуючи площа внутрішнього простору. Найчастіше через недостатне ущільнення самозаймання виникає на спланованих відвалах з пологими схилами $[1,3]$.

Другим чинником, що стимулює самозаймання, $\epsilon$ перебіг в тілі відвалів або териконів окислювальних процесів, внаслідок яких виділяється тепло, що сприяє розігріву порід у відвалі. Загоряння відбувається тоді, коли швидкість утворення тепла під час окиснення речовини перевищує швидкість його розсіювання. При горінні породних відвалів утворюються екотоксиканти, 3 яких найнебезпечніші газоподібні речовини: сірчаний ангідрид, сірководень, оксид карбону та сульфур. Виділяються також зважені частинки розміром менше 1 мікрона, які містять такі небезпечні речовини, як азбест, арсен, важкі метали. Потрапляючи в легені, вони призводять до незворотних процесів отруєння організму. У забрудненій атмосфері також присутні солі, сполуки нітрогену, сульфуру та радіонукліди [5].

Самозаймання лісових культур на териконах вугільних шахт виникає внаслідок самочинного горіння через поступове накопичення тепла. Зазвичай воно спостерігається під час різкого збільшення швидкості екзотермічних реакцій тоді, коли швидкість виділення тепла перевищує швидкість його розсіювання. Горіння териконів (через самозаймання органічних речовин, при цьому температура всередині терикона становить +100 $800{ }^{\circ} \mathrm{C}$ ) характеризується процесами термічного розкладу та випаровуванням небезпечних речовин, а також відбувається теплообмін між розігрітим відвалом та довкіллям. Унаслідок довготривалого горіння відбувається забруднення повітря вуглеводнями, пилом та іншими шкідливими речовинами, які виділяються від горіння. Процес самозаймання лісових культур на териконах може також перерости в ландшафтні пожежі, що призводять до великих економічних втрат і негативних екологічних наслідків.

Об'єкт дослідження - самозаймання та займання лісових культур.

Предмет дослідження - методи і засоби визначення особливостей розвитку самозаймання та займання найпоширеніших деревних порід (сосна звичайна, береза повисла, дуб звичайний, верба козяча) на териконах Нововолинського гірничопромислового району.

Мета роботи - дослідження температур займання та самозаймання найпоширеніших деревних порід териконів у межах Нововолинського гірничопромислового району.

Для досягнення зазначеної мети визначено такі основні завдання дослідження:
1) вивчити температуру самозаймання та займання лісових культур (сосна звичайна, береза повисла, дуб звичайний, верба козяча) на териконах вугільних шахт та їх вплив на довкілля;

2) визначити основні екологічні чинники, які впливають на розвиток горіння лісових культур на териконах шахтних порід;

3) оцінити температуру самозаймання та займання дерев (сосна звичайна, дуб звичайний, береза повисла, верба козяча) на териконах вугільних шахт.

Наукова новизна отриманих результатів дослідження - вперше розроблено методику, яка дала змогу дослідити особливості температури самозаймання та займання найпоширеніших деревних порід на териконах Нововолинського гірничопромислового району Львівсько-Волинського вугільного басейну.

Практична значущість результатів дослідження визначені температури самозаймання й займання деревних порід на териконах шахтних відходів дадуть змогу провести оцінювання екологічної безпеки території під час процесу горіння рослинного покриву териконів вугільних шахт.

Аналіз останніх досліджсень та публікацій. Причини виникнення пожеж на териконах вугільних шахт розглянуто у низці публікацій науковців [10]. Автори показують, що схильність до самонагрівання і самозаймання мають вуглисто-глинисті породи, з підвищеною поруватістю та вмістом піриту і марказиту. Розігрівання порід пояснюють окисненням сульфідів, яке відбувається за участі тіонових бактерій (Thiobacillus ferrooxidans). Умовою їх життєдіяльності є наявність кисню та вугільної кислоти. У міру розігрівання породи тіонові бактерії змінюють свою форму і продовжують діяти до температури $+1000{ }^{\circ} \mathrm{C}$ в середовищі з $\mathrm{pH}$ близьким до одиниці.

Сутність самозаймання відвалів, що містять вугілля, на думку вчених [4], полягає в тому, що вугілля сорбує на своїй поверхні з повітря молекулярний кисень, який утворює $з$ карбоном нестійку пероксидну сполуку, яка легко розкладається, виділяючи при цьому активний кисень, який окислює вугілля і перетворює його в багаті киснем стійкі сполуки. Оскільки цей процес екзотермічний, то він супроводжується підвищенням температури, пришвидшується процес окиснення, що призводить до самозаймання всього відвалу. Вміст сірки у відвалах досягає $10 \%$ (сульфідна сірка - до $84 \%$ ), а іï окиснення здійснюється тіоновими бактеріями. Це зазвичай автотрофні мікроорганізми, що використовують $\mathrm{CO}_{2}$ для побудови свого тіла й отримують енергію під час окиснення сірки і їі відновлених продуктів. Описане вище окиснення і горіння породних відвалів супроводжується значним виділенням водяної пари, яка є мінералоутворювальним середовищем для більшої частини мінералів: сульфатів, гідрокарбонатів, карбонатів, фосфатів, арсенатів. Окрім цього, під час окиснення виділяється вуглекислота, нітроген оксид (IV), який 3 водою утворює нітратну кислоту. У разі нестачі кисню в осередках горіння в парогазових викидах міститися сірководень, вуглеводні, амоніак, оксид карбону (II) [2].

Науковці [6] наводять такі чинники, що сприяють процесам самозаймання вугільних відвалів:

- процес самозаймання активізується у присутності вологи, за наявності стадій висихання і зволоження, оскільки сушіння вугільної матриці в процесах втрати води збільшує 
кількість пор. У Нововолинському гірничопромисловому районі кількість опадів практично повсюдно більше 300 мм/рік, саме тому сушіння вугільної матриці відбувається досить активно.

- швидкість окиснення вугілля зростає 3 підвищенням зовнішньої температури. Особливо це важливо у разі розташування вугільних відвалів у теплому кліматі. За своєю природою, вугілля не схильне до самозаймання, але при переміщенні його у відвали в умовах теплого клімату, може загорятися. У Нововолинському гірничопромисловому районі температура поверхні на схилах у спекотні дні може досягати $+41-42^{\circ} \mathrm{C}$, що стимулює активізацію процесів окиснення.

- теплопровідність вугілля може впливати на можливість виникнення процесів самозаймання, адже воно виконує функцію передачі й акумуляції тепла, що утворюється за окислення. Теплопровідність зазвичай буває вища у разі високої концентрації мінеральних речовин у складі вугілля, тому що вони швидше розсіюють тепло. Кількість мінеральних речовин у відвалах Нововолинського гірничопромислового району в середньому становить $10-20 \%$. Окиснення вугілля посилюється на дрібних частинках, через збільшення площі поверхні, що доступна для окиснення. У відвалах Нововолинського гірничопромислового району вугільна складова знаходиться в подрібненому стані, тому такі відвали більше схильні до самозаймання, ніж вихідне вугілля. Як видно із наведених вище факторів, в умовах досліджуваних териконів Нововолинського гірничопромислового району, самозаймання відвалів є частим процесом і їх кількість на рік буде значною.

Аналізуючи результати досліджень науковців [11] стосовно самозаймання вугілля, можна виділити декілька стадій:

- фізична адсорбція кисню з виділенням тепла і послідовне збільшення кількості тепла;

- хімічна сорбція за температури від $+50{ }^{\circ} \mathrm{C}$;

- руйнування оксивмісних вуглеводнів, за температури самонагрівання $\left(+70^{\circ} \mathrm{C}\right)$ і вивільнення кисню, який далі окислює незмінену речовину вугілля.

- самозаймання може відбуватися, коли всі ці процеси призводять до накопичення тепла і зростання температури до $+150^{\circ} \mathrm{C}$.

За температури більше $+300{ }^{\circ} \mathrm{C}$ відбувається розкладання мінералів і вуглецевмісної речовини з виділенням чадного газу (CO), вуглекислоти $\left(\mathrm{CO}_{2}\right)$, азоту $\left(\mathrm{N}_{2}\right)$, оксиду сульфуру $\left(\mathrm{SO}_{2}\right)$. При температурах $+480-520{ }^{\circ} \mathrm{C}$ відбувається утворення амоніаку $\left(\mathrm{NH}_{3}\right)$; при температуpi $+500-550{ }^{\circ} \mathrm{C}$ виділяється водень $\left(\mathrm{H}_{2}\right)$, монооксид карбону (СО) і важкі вуглеводні; при температурі +900$1200{ }^{\circ} \mathrm{C}$ утворюється сірковуглець $\left(\mathrm{CS}_{2}\right)$, карбону оксисульфід (COS), тіофен $\left(\mathrm{C}_{4} \mathrm{H}_{4} \mathrm{~S}\right)$. За температури +800 $1200{ }^{\circ} \mathrm{C}$ порода вугільних відвалів зазнає термального метаморфізму, тобто відбувається часткове плавлення i випал шахтних порід, а також утворення гематиту, муліту, шпінелі тощо [14].

Відомо, що займання териконів - це перехід хімічної системи 3 низькотемпературного окиснення у стан горіння терикона, а самозаймання териконів - явище стрімкого збілышення швидкості екзотермічних реакцій, що призводить до виникнення горіння шахтної породи за відсутності джерела запалювання. Відповідно до правил пожежної безпеки для підприємств вугільної промисловості України [8] найнадійнішим способом захисту від займання та самозаймання відвалів вугільних шахт $\epsilon$ розроблення проекту протипожежного захисту, тобто застосування пожежобезпечних схем розкриття i підготовки шахтних полів, систем розробки відвалів вугілля, схильного до самозаймання, заходи із запобігання пожежам від самозаймання териконів, а також швидкої локалізації і активного гасіння пожежі.
Низький рівень заліснення териконів Львівсько-Волинського вугільного басейну визначається значним засоленням і високою концентрацією водорозчинних солей, кількість і якість яких тісно пов'язані з $\mathrm{pH}$ [1]. Субстрати цих відвалів переважно характеризуються слабо кислим та нейтральним показником середовища (pH 6,1-7,2). Загальна засоленість визначається вмістом сульфат-іона $\left(\mathrm{SO}_{4}{ }^{2-}\right)$, вміст яких у териконах ЛьвівськоВолинського вугільного басейну варіює в межах 0,160 0,683 г / 100 г. Вміст інших токсичних солей (сульфіти, нітрати, нітрити) у пробах грунту з відвалів шахт варіює в межах 0,02-0,35 \% [3].

Матеріали та методи дослідження. Вирішення поставлених у роботі завдань здійснювали з використанням системного підходу в доборі матеріалу, методів індуктивного і логічного аналізу, спостереження та статистичні методи аналізу літературних даних.

Дослідження показників займання та самозаймання твердих речовин і матеріалів проводили у весняний період. Досліджуваними об'єктами були зразки деревних порід з терикону шахти Нововолинського гірничопромислового району (Волинська область, м. Нововолинськ). Умови експерименту станом на 19.05.2020 р.: Температура $+19,0{ }^{\circ} \mathrm{C}$, атмосферний тиск 97,5 кПа. Умови експерименту $24.08 .2020 \mathrm{p} .:$ температура $+22,0{ }^{\circ} \mathrm{C}$, атмосферний тиск - 97,2 кПа, відносна вологість $60,0 \%$.

Для визначення температури займання твердих речовин та матеріалів згідно з пунктом 7.8 ДСТУ 8829:2019 використали зразки хвої сосни звичайної з терикону шахти Нововолинського гірничопромислового району (Волинська область, м. Нововолинськ). У роботі використовували метод експериментального визначення температури займання твердих речовин і матеріалів, згідно $з$ яким, за температуру займання брали покази термоелектричного перетворювача, що вимірює температуру зразку. Методом послідовних наближень визначали мінімальну температуру зразку, за якої за час витримки в печі не більше 20 хв зразок займався і горів більше 5 с після віддалення пальника. За температуру займання досліджуваного матеріалу приймали середне арифметичне значення двох температур, що відрізнялися не більше ніж на $+10^{\circ} \mathrm{C}$, при одній з яких спостерігалося займання трьох зразків, а при іншій - три відмовлення.

Згідно з вимогами ДСТУ 8829:2019 "Пожежовибухонебезпечність речовин і матеріалів. Номенклатура показників і методи їх визначення. Класифікація", використано метод експериментального визначення температури займання твердих речовин і матеріалів, який реалізується в діапазоні температур від +25 до $+600{ }^{\circ} \mathrm{C}$ i незастосовний для випробування металевих порошків. Для випробування було приготовлено 10-15 зразків досліджуваної речовини (матеріалу) масою $\left(3,0^{ \pm 0,1}\right)$ гр. Зразки матеріалів мали циліндричну форму діаметром $\left(45^{ \pm 1}\right)$ мм, плівкові і листові матеріали набирали у стопку діаметром $\left(45^{ \pm 1}\right)$ мм, накладаючи шари один на одного до досягнення зазначеної маси.

Перед випробуванням зразки кондиціонували за відносності вологості $50 \%$, температури $+23{ }^{\circ} \mathrm{C}$ упродовж 4 год, згідно з вимогами ДСТУ EN ISO 291:2017 "Пластмаси. Стандартні атмосферні умови для кондиціонування й випробувань". 


\section{Результати дослідження та їх обговорення}

У породі відвалів Львівсько-Волинського вугільного басейну найчастіше домінують хрящуваті і кам'янисті фракції і вони не дуже сприяють росту на дерев. Для оцінювання рівня впливу на довкілля продуктів горіння і необхідних умов самозаймання лісових культур на териконах вугільних шахт Нововолинського гірничопромислового району ми вибрали такі дерева, як береза повисла, сосна звичайна, дуб звичайний та верба козяча.

Отримане значення температури займання матеріалу зразків лісових культур заокруглено з точністю до +5 ${ }^{\circ} \mathrm{C}$ (табл. 1). Аналізуючи отримані результати, можна зробити висновок про те, що температура займання зразку сосни звичайної становить $+225^{\circ} \mathrm{C}$.

Табл. 1. Результати експериментального вимірювання температури займання матеріалу зразків лісових культур (сосна звичайна)

\begin{tabular}{|c|c|c|}
\hline $\begin{array}{c}\text { № } \\
\text { зразка }\end{array}$ & $\begin{array}{c}\text { Температура випробування, } \\
{ }^{\circ} \mathrm{C}\end{array}$ & $\begin{array}{c}\text { Результат } \\
\text { випробування }\end{array}$ \\
\hline 1 & +220 & відмова \\
\hline 2 & +220 & відмова \\
\hline 3 & +220 & відмова \\
\hline 4 & +230 & займання \\
\hline 5 & +230 & займання \\
\hline 6 & +230 & займання \\
\hline
\end{tabular}

Для визначення температури самозаймання зразка сосни звичайної згідно з ДСТУ 8829:2019 "Пожежовибухонебезпечність речовин і матеріалів. Номенклатура показників і методи їх визначення. Класифікація" (п. 7.10.) використали метод експериментального визначення температури самозаймання твердих речовин і матеріалів. Отримане значення температури заокруглено 3 точністю до $+5^{\circ} \mathrm{C}$ (табл. 2). Наведені в таблиці результати свідчать про те, що, згідно з п. 7.10 ДСТУ 8829:2019, температура самозаймання взірця сосни звичайної становить $+475^{\circ} \mathrm{C}$.

Табл. 2. Результати експериментального вимірювання температури самозаймання зразків лісових культур (сосна звичайна)

\begin{tabular}{|c|c|c|}
\hline $\begin{array}{c}\text { № } \\
\text { зразка }\end{array}$ & $\begin{array}{c}\text { Температура випробування, } \\
{ }^{\circ} \mathrm{C}\end{array}$ & $\begin{array}{c}\text { Результат випробу- } \\
\text { вання }\end{array}$ \\
\hline 1 & +460 & відмова \\
\hline 2 & +460 & відмова \\
\hline 3 & +460 & відмова \\
\hline 4 & +470 & самозаймання \\
\hline 5 & +470 & самозаймання \\
\hline 6 & +470 & самозаймання \\
\hline
\end{tabular}

За температуру займання досліджуваного матеріалу приймали середнє арифметичне двох температур, що відрізнялися не більше ніж на $+10^{\circ} \mathrm{C}$, за однієї з яких спостерігається займання трьох зразків, а за іншої - три відмовлення. Отримане значення температури заокруглено $з$ точністю до $+5^{\circ} \mathrm{C}$ (табл. 3 ).

Табл. 3. Результати експериментального вимірювання температури займання зразків лісових культур (береза повисла, дуб звичайний, верба козяча)

\begin{tabular}{|c|c|c|c|c|}
\hline \multirow{2}{*}{$\begin{array}{c}\text { № } \\
\text { зразка }\end{array}$} & \multicolumn{3}{|c|}{ Температура випробування, ${ }^{\circ} \mathrm{C}$} & \multirow{2}{*}{$\begin{array}{c}\text { Результат } \\
\text { випробуван- } \\
\text { ня }\end{array}$} \\
\hline & $\begin{array}{c}\text { Береза по- } \\
\text { висла }\end{array}$ & $\begin{array}{l}\text { Дуб зви- } \\
\text { чайний }\end{array}$ & $\begin{array}{c}\text { Верба козя- } \\
\text { ча }\end{array}$ & \\
\hline 1 & +250 & +270 & +275 & відмова \\
\hline 2 & +250 & +270 & +275 & відмова \\
\hline 3 & +250 & +270 & +275 & відмова \\
\hline 4 & +260 & +280 & +285 & займання \\
\hline 5 & +260 & +280 & +285 & займання \\
\hline 6 & +260 & +280 & +285 & займання \\
\hline
\end{tabular}

Аналізуючи отримані результати 3 табл. 3, можна зробити висновок про те, що згідно 3 п. 7.8 ДСТУ 8829:2019 температура займання матеріалу зразків становить: берези повислої $-+260{ }^{\circ} \mathrm{C}$, дуба звичайного $-+280{ }^{\circ} \mathrm{C}$, козячої верби $-+285^{\circ} \mathrm{C}$.

Ми дослідили показники температури самозаймання твердих речовин і матеріалів для досліджуваних порід дерев згідно з ДСТУ 8829:2019. В експерименті використовували метод експериментального визначення температури самозаймання твердих речовин і матеріалів, що застосовний в діапазоні температур від +25 до $+600{ }^{\circ} \mathrm{C}$ і незастосовний для випробування металевих порошків.

За температуру самозаймання досліджуваного матеріалу приймали середнє арифметичне двох температур, що відрізнялися не більше ніж на $+10^{\circ} \mathrm{C}$, за однієї 3 яких спостерігалось займання трьох зразків, а за іншої три відмовлення. Отримане значення температури заокруглено 3 точністю до $+5^{\circ} \mathrm{C}$ (табл. 4). Аналізуючи отримані результати, можна зробити висновок про те, що згідно з п. 7.10 ДСТУ 8829:2019 температура самозаймання матеріалу зразків становить: берези повислої -+475 ${ }^{\circ} \mathrm{C}$, дуба звичайного $-+480{ }^{\circ} \mathrm{C}$, козячої верби $-+473{ }^{\circ} \mathrm{C}$.

Табл. 4. Результати експериментального вимірювання температури самозаймання матеріалу зразків лісових культур (береза повисла, дуб звичайний, верба козяча)

\begin{tabular}{|c|c|c|c|c|}
\hline \multirow[b]{2}{*}{$\begin{array}{c}\text { № } \\
\text { зразка }\end{array}$} & \multicolumn{3}{|c|}{ Температура випробування, ${ }^{\circ} \mathrm{C}$} & \multirow{2}{*}{$\begin{array}{c}\text { Температура } \\
\text { випробування, } \\
{ }^{\circ} \mathrm{C}\end{array}$} \\
\hline & $\begin{array}{c}\text { Береза по- } \\
\text { висла }\end{array}$ & $\begin{array}{l}\text { Дуб зви- } \\
\text { чайний }\end{array}$ & $\begin{array}{c}\text { Верба козя- } \\
\text { ча }\end{array}$ & \\
\hline 1 & +465 & +470 & +463 & відмова \\
\hline 2 & +465 & +470 & +463 & відмова \\
\hline 3 & +465 & +470 & +463 & відмова \\
\hline 4 & +475 & +480 & +473 & самозаймання \\
\hline 5 & +475 & +480 & +473 & самозаймання \\
\hline 6 & +475 & +480 & +473 & самозаймання \\
\hline
\end{tabular}

Займання або самозаймання рослинного покриву на териконах вугільних шахт призводить до високих рівнів забруднення довкілля. На сьогодні методом подолання наслідків самозаймання лісових культур териконів вугільних шахт можна запобігти горінню териконів, а цьому сприяє процес природного заростання териконів, а також підвищення фітомеліоративної ефективності природного і штучно створеного рослинного покриву $[12,13]$. Унаслідок проведених досліджень встановлено, що на території Нововолинського гірничопромислового району на териконах лісові культури здатні самозайматися та запобігають процесам самозаймання териконів (рисунок).

Проаналізувавши наведені вище дані можна чітко констатувати той факт, що шахтні відвали дуже негативно впливають на навколишнє середовище і людини, при цьому ще і займаючи великі площі родючих земель. Вкрай необхідно розвивати технології утилізації териконів, створюючи нові високопродуктивні переробні комплекси. Переробка шахтних териконів також дасть нові робочі місця людям, які проживають в шахтарських містах і селищах.

Варто зазначити, що палаючі терикони, які знаходяться на значному видаленні від споживачів тепла, найбільш перспективно використовувати, коли $є$ можливість розташувати споживача тепла поруч або перетворити теплову енергію в електричну. Палаючі терикони, які знаходяться на значному видаленні від населених пунктів, найбільш перспективні на даний момент 
часу з позиції їх швидкого використання (відпрацювання дослідної технології, безпеки, екологічної чистоти), оскільки в процесі відпрацювання пом'якшуються деякі вимоги, що пред'являються санітарно-гігієнічними та екологічними службами. Найбільш перспективним напрямом їх використання є отримання електроенергії та хімічних продуктів [18].

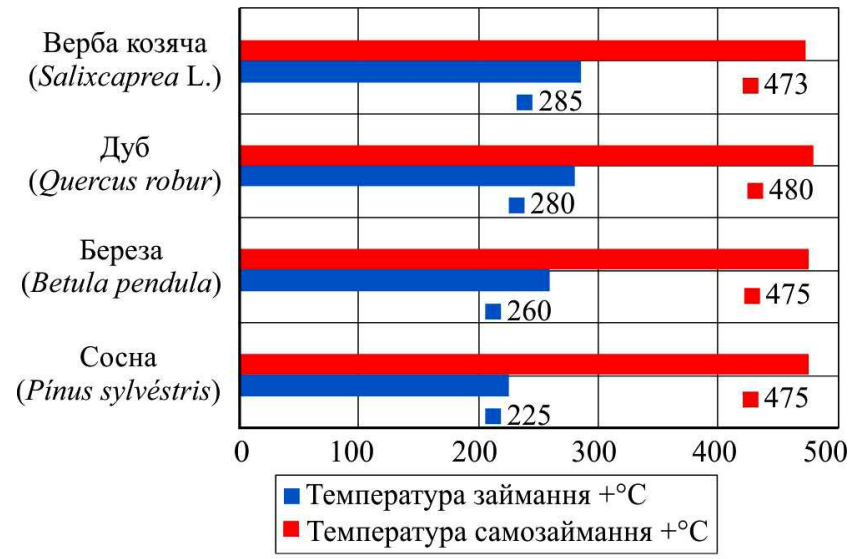

Рисунок. Аналіз самозаймання та займання лісових культур на териконах вугільних шахт Нововолинського гірничопромислового району

\section{Висновки}

Отже, наголошено на значному екологічному впливі териконів Нововолинського гірничопромислового району на довкілля. Також зазначено чинники, які призводять до самозаймання вугільних відвалів, та детально описано механізм досліджуваних процесів. Показано, що найнадійнішим способом захисту від самозаймання вугільних відвалів є створення на їх поверхні рослинного покриву.

За результатами дослідження встановлено показники температури займання та самозаймання твердих речовин і матеріалів (сосни звичайної, берези повислої, дуба звичайного, верби козячої) згідно з ДСТУ 8829:2019. Експериментально визначено, що для сосни звичайної температура займання становить $+225^{\circ} \mathrm{C}$, а самозаймання $-+475^{\circ} \mathrm{C}$. Температура займання берези повислої становить $+260{ }^{\circ} \mathrm{C}$, дуба звичайного $-+275^{\circ} \mathrm{C}$, козячої верби $-+280^{\circ} \mathrm{C}$, температура самозаймання берези повислої $-+470{ }^{\circ} \mathrm{C}$, дуба звичайного $-+475{ }^{\circ} \mathrm{C}$, верби козячої $-+473{ }^{\circ} \mathrm{C}$, а також досліджено, що вища температура займання берези повислої, дуба звичайного, верби козячої, порівняно із сосною звичайною, робить їх перспективними породами дерев для проведення рекультиваційних робіт і як наслідок - для запобігання самозайманню вугільних відвалів.

\section{References}

1. Babadzhanova, O. F., Sukach, Yu. H., \& Sukach, R. Yu. (2012). Factors of fire danger of waste heaps of coal mining. Fire Safety $L D U B G D, 20,137-143$. [In Ukrainian].

2. Bosak, Pavlo, \& Popovych, Vasyl, Stepova, Kateryna, \& Dudyn, Roman. (2020). Environmental impact and toxicological properti- es of mine dumps of the Lviv-Volyn coal basin. News of the National Academy of Sciences of the Republic of Kazakhstan. Series of geology and technical sciences, 2(440), 48-54 https://doi.org/10.32014/2020.2518-170X.30

3. Bosak, Pavlo, \& Popovych, Vasyl. (2019). Radiation-ecological monitoring of coal mines of Novovolinsk mining area. News of the National Academy of Sciences of the Republic of Kazakhstan. Series of geology and technical sciences, 5(437), 132-137. https://doi.org/10.32014/2018.2518-170X.134

4. Chobot'ko, I. I., \& Tynyna, S. V. (2018). Methods and means of localization of foci of spontaneous combustion of waste heaps. Geotechnical mechanics, 142, 134-140. [In Ukrainian].

5. Fel'dman, E. P., Kaluhina, N. O., \& Chesnokova, O. V. (2018). Mathematical model of heat transfer in the coal seam at great depths. Physical and technical problems of mining, 20, 9-14. [In Ukrainian].

6. Kachurin, N. M., Yefimov, V. I., Mosina, Ye. K., \& Faktorovich, V. V. (2014). Prospects for the environmentally safe use of industrial waste in the territories of mining regions. Industrial safety, 9, 81-84. [In Russian].

7. Kusnetsov, V. V., \& Shevyakova, N. I. (1997). Stress responses of tobacco cells to high temperature and salinity. Proline accumulation and phosphorylation of polypeptides. Physiol. Plant, 100, 320-326.

8. NAPB B 01.009-2004. (2004). Fire safety rules for enterprises of the coal industry of Ukraine (3379). Retrieved from: https://dnaop.com/

9. Paleg, L., Stevart, G. R., \& Bradbeer, J. W. (1994). Proline and glicine betaine in fluences protein salvation. Plant Physiol, 75, 974-978.

10. Pavlychenko, A. V., \& Kulyna, S. L. (2015). Man-caused consequences of closure of coal mines of Chervonohrad mining region. Ecologist Week-2015: reports of the international scientific symposium, (pp. 141-143). Dniprodzerzhynsk: DSTU. [In Ukrainian].

11. Pavlychenko, A. V., \& Plakhotniy, S. A. (2016). Ways to reduce the negative impact of waste heaps of liquidated mines on the ecological condition of coal mining regions. Miners Forum - 2016: materials of the international conference, 2, 229-233. Dnipro: NMU. [In Ukrainian].

12. Popovich, V. V. (2016). Phytomeliorative recovery in reduction of multi-element anomalies influence of devastated landscapes. Biological Bulletin of Bogdan Chmelnitskiy Melitopol State Pedagogical University, 6(1), 94-114. https://doi.org/10.15421/201606

13. Popovych, V. V., \& Pinder, V. F. (2018). Waste heaps burning as a landscapes transforming factor of regional environmental hazards growth. Bulletin of Lviv State University of Life Safety, 29, 116-124. [In Ukrainian].

14. Popovych, V. V., Pidhorodetsky, Ya. I., \& Pinder, V. F. (2016). The typology of heaps of Lviv-Volyn Coal Basin. Scientific Bulletin of UNFU, 26(8), 238-243. https://doi.org/10.15421/40260837

15. Popovych, V., Kuzmenko, O., Voloshchyshyn, A., \& Petlovanyi, M. (2018). Influence of man-made edaphotopes of the spoil heap on biota. E3S Web of Conferences. Vol. 60. 00010. https://doi.org/10.1051/e3sconf/20186000010

16. Radchenko, V. V., Kulish, V. A., Chepiha, Ye. V., \& Storozhchuk, V. S. (2013). Condition of waste heaps of domestic coal mines. Coal of Ukraine, 12, 44-45. [In Ukrainian].

17. Regional report on the state of the environment of Volyn region in 2019. Title of resources. Retrieved from: https://voladm.gov.ua/article/regionalna-dopovid-pro-stan-dovkillya/

18. Saranchuk, V. M. (1978). Borba s goreniem porodnykh otvalov. Kyiv: Scientific thought, 268 p. [In Russian].

P. V. Bosak, V. V. Popovych, V. F. Pinder, O. V. Stokalyuk Lviv State University of Life Safety, Lviv, Ukraine

\section{IGNITION AND SPONTANEOUS IGNITION TEMPERATURE OF WIDESPREAD WOODY SPECIES ON THE WASTE HEAPS}

The environmental threat of mine waste heaps in an urban area is supposed to be high. For its assessment the environmental monitoring is required for development of environmental measures to minimize negative impacts. The factors that lead to spontaneous 
ignition of coal heaps are emphasized and based on scientific information sources the chemistry of the investigated processes is described in detail. Oxidation and ignition of waste heaps is followed by a significant release of water vapour, which is a mineral-forming environment for most minerals: sulfates, bicarbonates, carbonates, phosphates and arsenates. In addition, oxidation releases carbon dioxide, nitrogen oxide (IV), which forms nitric acid with water. Faced with the lack of oxygen in the combustion chambers the gas emissions contain hydrogen sulphide, hydrocarbons, ammonia, and carbon monoxide. The role of sulphur in oxidation processes is emphasized. The oxidation of coal is enhanced by fine particles, due to the increase in surface area available for oxidation. It is shown that the most reliable way to protect coal heaps against spontaneous ignition is to create vegetation on their surface. The process of vegetation formation is very important, as it involves both the accumulation of heavy metals in plants and the binding of the substrate to their roots and rhizomes, which reduces the process of weathering and leaching of rock that contains heavy metals. Indicators of ignition and spontaneous ignition point of woody species heaps of coal mines according to DSTU 8829: 2019 are determined. Investigation of ignition and spontaneous ignition of solids and materials were conducted in spring and summer. The samples of leaves and wood from the heap of the mine of Novovolynsk mining area (Volyn region, Novovolynsk) were investigated. It was established that the ignition temperature of the Scots pine is $+225^{\circ} \mathrm{C}$ and the spontaneous ignition occurs at $+475{ }^{\circ} \mathrm{C}$. The ignition point of birch is $+260{ }^{\circ} \mathrm{C}$, oak $-+275^{\circ} \mathrm{C}$, goat willow $-+280^{\circ} \mathrm{C}$, the spontaneous ignition temperature of birch is $+470{ }^{\circ} \mathrm{C}$, oak -+475 ${ }^{\circ} \mathrm{C}$, goat willow $-+473{ }^{\circ} \mathrm{C}$. The ignition temperature of birch, oak, willow is higher than pine which makes them promising tree species to prevent spontaneous ignition of coal heaps.

Keywords: ecological safety; environmental threat; ignition; waste heap; Novovolynsk mining area. 